\title{
Peuista Leteas Pacas
}

ISSN: 2317-2347 - v. 9, n. 2 (2020)

Todo o conteúdo da RLR está licenciado sob Creative Commons Atribuição 4.0 Internacional

\section{Filarmônica}

\section{Eliseu Raphael Venturi”}

Doutor em Direito pela Universidade Federal do Paraná, UFPR (2019). Licenciado em Artes Visuais pela Faculdade de Artes do Paraná, FAP/PR (2006).

\section{iD https://orcid.org/0000-0001-9096-2825}

Recebido: 19 abr. 2020. Aprovado: 07 jun. 2020.

Como citar este texto:

VENTURI, Eliseu Raphael. Filarmônica. Revista Letras Raras. Campina Grande, v. 9, n. 2, p. 327-328, jun. 2020.

Noite exaustiva adentro temendo o alvorecer do mundo novo, toca-me a filarmônica de Berlim, que jamais conheci ou conhecerei, apenas me toca e não quero a Ciência nem a catalogação dos instrumentos que eu gostaria de descrever em suas curvas e arquiteturas acertadas, nem 0 gabarito de partitura e a complicação das notas e das escalas e das matemáticas, ou o panteão dos compositores, um sensualista, eu apenas ouço os ventos e os atritos, as madeiras e os metais, o calor das respirações e a disciplina dos corpos exaustivamente treinados em seus movimentos perfeitos, precisos, certeiros, oportunos, tempestivos, como acrobatas e ginastas sem deslocamento em um espetáculo de regras, quadros, medidas, proporções áureas, diante do que um homem calcula, uma mulher sorri discretamente, alguém ali está sendo levado para outro lugar, eu estou sendo levado para outro lugar que é o texto que me interpela, quando por um décimo de segundo eu apenas intuo que todo o incômodo do mundo novo ou velho desaparece, e toda angústia perde o sentido, a função e o elogio, como um anestésico da vigilância que consagrou as drogadições todas, um anticorpo da realidade virótica sem léxico metafísico, um encerramento da música industrial incessante de estocadas infinitas, eu sinto que ali naquele décimo de segundo há a fuga e eu vejo o caminho, o que se dispersa, sem se interromper, no aplauso da plateia, aplausos sincronizados são patéticos e aplausos apenas vão bem quando cada um aplaude na

\section{$\triangle$ eliseurventuri@gmail.com}




\section{Peuista Letras Parar}

ISSN: 2317-2347 - v. 9, n. 2 (2020)

Todo o conteúdo da RLR está licenciado sob Creative Commons Atribuição 4.0 Internacional

sua velocidade, intensidade, densidade, como agradecimento ou expressão dos alcances, uma forma de comunicação muito completa e bela, o som amorfo dos aplausos é o que lhes confere a beleza da margem como chuvisco, e nessa nova música anárquica, mas ainda regrada, as pessoas sorriem, mas não se vêem dentes, todos os sorrisos são discretos e todos os olhares do deleite estético estão para fora como capacidade de olhar para o silêncio, de dominar o espaço, há mil ruídos que podem atravessar tal devaneio único, eu sei, há mil desconfianças, mil dedos, mil teorias, mil reversões, mil desmascaramentos, mil análises, eu já carreguei todas estas coisas que me entortaram à esquerda e à direita e me calejaram em prol de outros abjetos, eu expulso todos, não Ihes dou mais ouvidos, nem coração, nem as costas, eu apenas sei da verdade daquele instante de intuição profunda, a beleza de certas formas de comunicação, o significado da orquestra e o tanto que se pode usá-la como metáfora, e é a esta intuição que me apego, cuido, preservo, porque eu sei que nela está a contraface da pobreza do mundo, este mundo que se destece e se retece em um capítulo sempre piorado. 